\title{
'Diia. Digital state' and E-Government Practices as Anti-Corruption Tools in Ukraine
}

\author{
KOSTYANTYN B. MARYSYUK \\ Department of Criminal Law and Procedure, Institute of Jurisprudence, Psychology and Innovative \\ Education, \\ Lviv Polytechnic National University \\ 12 S. Bandery Street, 79000, \\ Lviv, UKRAINE
}

\section{INNA O. TOMCHUK}

Department of Law, Legal Faculty, Halytskyi College named after Vyacheslav Chornovil,

15, B. Khmelnytskyi Street, 46001, Ternopil, UKRAINE

\author{
MYKHAILO D. DENYSOVSKYI \\ Department of Law, Legal Faculty, \\ Halytskyi College named after Vyacheslav Chornovil, \\ 15, B. Khmelnytskyi Street, 46001, \\ Ternopil, UKRAINE \\ IRYNA O. GELETSKA \\ Halytskyi College named after Vyacheslav Chornovil, \\ 15, B. Khmelnytskyi Street, 46001, \\ Ternopil, UKRAINE
}

\section{BOHDAN V. KHUTORNYI}

Department of Public Administration and Administration, Educational and Scientific Institute of Management, Economy and Nature Management, V. I. Vernadsky Taurida National University,

33 John McCain Street, 01042, Kyiv, UKRAINE

\begin{abstract}
The research is topical due to complex structure and multifactority of corruption in transition countries, its overcoming and prevention. The study is aimed to identify opportunities and assess the political experience of anti-corruption practices in transition countries, based on analysis of anti-corruption policy, in part e-government. Case study methods, systemic analysis of modernization processes in the political systems of transition countries, structural and functional analysis of anti-corruption policy, methods for predicting the success of transit processes in countries, modeling plausible scenarios of these processes were applied. Transitional systems are highly corrupt. There is institutional corruption in transition countries, i.e. corruption that has become a special institution regarding traumatic social transformation. The reason for institutionalization of corruption is weakness of transitional states, which has not yet become democratic. The use of information technology in political management becomes one of the leading criteria for democratization of political institutions, openness of political systems. Optimization of anti-corruption practices involves in part introduction of e-government. The consideration of e-government is methodologically comprehensive. The consequences of corruption relate to the redistribution of budget funds, various economic benefits, which are not always good for citizens. Economic growth is slowing down, the priorities of socio-economic development are distorted, the labor and entrepreneurial motivation of economic agents, is distorted. The experience of modernization of transformations and political reforms in different regions shows that one of the main factors determining specifics of political process is effectiveness of national models of anti-corruption practices in interests of citizens.
\end{abstract}

Key-Words: - E-Government, Good Governance, E-Government Concept, Political Modernization, Transit State. Received: February 17, 2021. Revised: July 24, 2021. Accepted: July 31, 2021. Published: August 5, 2021. 


\section{Introduction}

The complex processes of public administration developing in transition countries are primarily related to understanding the conditional factors that can replace the democratization of the political system, increase the efficiency of political institutions, are included in transparent forms and mechanisms of government interaction and civic initiative. The context of modern public relations in most transit countries associates with corruption interactions, which indicates the global scale of the phenomenon and the need to combat it [1]. The countries that actively use the methods of legal and public control have achieved significant results in reducing corruption through the implementation of administrative reform and the introduction of new technological communications in the system of public administration and public services [2]. At the same time, modern achievements in the field of Internet communications contribute to the modernization of society, the transition to its information stage of development, largely determine the architecture of political and government institutions [3, 4].

Corruption has been and remains one of the global challenges facing modern states [1]. Although corruption has long been known, its role as a socioeconomic and political phenomenon has only been fully realized in the last three to four decades [5]. The border of the 20th-21st centuries is marked by a noticeable interest in the problem of corruption. It is estimated that while in the early 1990's the word "corruption" appeared in the pages of influential economic and political publications in Europe about 500 times a year on average, ten years later this figure rose more than 6 times [6].

Transit countries are particularly vulnerable to corruption. Under the conditions when such states are on the stage between authoritarianism and have not yet reached democracy, their bureaucracy is virtually out of control by both political power and civil society. Therefore, it serves not the state and society, but itself. Scholars characterize this phenomenon as institutional corruption, when state power is monopolized not by large private owners (oligarchs), but by bureaucracy [7]. Practices of overcoming institutional corruption in transition countries are a relatively new problem for world science.
The development of the information society has affected all spheres of public life. Democracies have begun global transformations. Transformational changes have also affected public administration, creating new opportunities to combat the negative factors that accompany democracy, including corruption. Corruption in transition countries is a systemic phenomenon [8]. The realities of a developed democracy require the introduction of electronic document management, the provision of public services in electronic format, the translation of information into digital format instead of paper, which, in turn, creates a favorable context for the fight against corruption. Electronic public services reduce the likelihood of direct contact between a citizen and a public servant.

A significant factor in increasing public attention to corruption has been the implementation of profound reforms in the post-socialist space and the awareness of the need to limit a negative accompanying factor of reforms - corruption [9]. According to the Transparency International Corruption Perceptions Index, none of the postsocialist (transition) countries is included in the cluster of the least corrupt countries [10]. Only Slovenia has broken into the cluster of countries with an average level of corruption. This situation is of concern to public authorities and causes a significant strain of anti-corruption rhetoric in public discourse [11]. An important task of our study is to analyze the specifics of corruption in transition countries. It is important to know how the different versions of anticorruption strategies have manifested themselves in practice, what role the state should play in combating corruption, and what role civil society structures should play. The solution of this urgent problem is of considerable practical and theoretical interest.

The aim of this work is to analyze effective anticorruption practices in transition countries related to the development of modern information technologies and further development of transparency of public authorities. Important research objectives are the following: 1) describe the characteristic features of institutional corruption, analyze the challenges of its spread in transition countries; 2) reveal the possibilities of introduction and use of e-government models to overcome corruption under the conditions of political modernization of transition countries; 3 ) identify positive and negative factors influencing the 
implementation of the concept of digital state in Ukraine; 4) determine the resources and nature of the functioning of e-government, the dissemination of the e-democracy principles.

\section{Background}

It is generally accepted to distinguish the legal, sociological, public administration layers of scientific knowledge that reflect the analysis of corruption as a social phenomenon [12].

Currently, corruption is the subject of research by many scholars working in the social and behavioral sciences [13]. Modern theorists most often interpret corruption as an improper advantage that hinders the public interest [14]. In modern discourse, the study of corruption in transition countries focuses mainly on socio-philosophical, economic, legal and sociopolitical aspects [15].

Scholars view corrupt relationships in their association with social practice [16], representing a personal view of the relationship between civil society institutions and public authorities. The level of corruption in many countries is determined by socio-psychological characteristics and sociocultural traditions of different transition countries [17]. Moreover, parliamentary/non-parliamentary political parties, a number of civil society institutions in transition countries, which play the role of modernization actors, have different institutional resources and the degree of influence on anticorruption policy, among other things, due to insufficient dissemination of principles and elements of e-democracy in intra-party activities and in working with the population.

According to the economic and legal approach, corruption is closely linked to the concept of shadow economy, informal institutions and illegal actions of government entities [18]. This phenomenon is characterized as the selection and sale of civil servants, as well as the use of image position, abuse of power for benefits.

Another of the key issues that arise in the process of applying and expanding e-government systems is supporting the current and strategic resilience of cyberspace. The strategic resilience of cyberspace is not only vital to national security, but it also plays an important role in shaping the cyberspace agenda. Sustainable cyberspace can be seen as a balance between states in terms of cyber capabilities, conflict management mechanisms, and the security and development of related cyberspace. The state must adapt its cyber strategy to strategic competition with external influence based on the cyber defense system and strengthening its own cybernetic capabilities [19].

Cybersecurity policy in e-government realizes the following values: security, privacy, fairness, economic value and accountability. Security defines the protection of assets (tangible and intangible), personal information from harm. Loss of availability, integrity and disclosure of confidentiality leads to a decrease in value for the owners of the asset, including the state. Confidentiality allows interested parties (citizens, groups, legal entities) to restrict information about themselves, including the proper use and protection of data.

It should be noted that the further development of e-government requires significant financial and technological resources, which is possible with the joint work of both the state and private entities, involves the formation of new models of interaction in the development and protection of infrastructure, prevention of data theft and cyber espionage, distribution of powers, risks and functions.

\section{Methods and Materials}

In this study, economic-legal and socio-political approaches will be used in the corruption analysis. The study involved theoretical methods (analysis, synthesis, induction, deduction). The theoretical background of research consists of modernization theories and the institutional approach, which allowed to evaluate the practice of e-government as an anti-corruption institution in the context of building up national models of political modernization. Other methodologically valuable theories that can be attributed to the theoretical background of research are the theory of bureaucracy social self-organization and the theory of communication in administrative and political reforms

The method of comparative analysis was used to identify important areas of public administration policy to combat corruption, ensuing democratization, observance of human and civil rights in countries at different stages of transition to the information society.

The study involved such a qualitative research method as the analysis of regulations (the scope of regulatory support for anti-corruption practices and relations to prevent corruption).

The empirical background of the study was a numerical analysis and interpretation of several types of sources: international corruption indices Transparency International Corruption Index [10], and the development of UN e-government [20], correlation surveys of public opinion monitoring in media materials, Internet resources of political 
organizations, public authorities and administration, local self-government, etc. The Digital State project in Ukraine was investigated.

The hypotheses of the study are the following statements:

1) if the anti-corruption practice develops on the basis of three main schemes of information interaction: government to citizens; government to governance; government to business - it is likely to be successful in transition countries;

2) if the legal and public control over the governing bodies with the use of modern communication methods will continuously develop, the resistance to the introduction of anti-corruption practices by public servants will constantly decrease;

3 ) if the anti-corruption activities of the branches of government have sufficient legal (legislative) support of the anti-corruption process, adequate human resources for e-government, will be accompanied by a high level of coordination of decisions and actions between different authorities and management, anti-corruption practices are highly likely to be successful.

\section{Results}

Political modernization, which is an integral part of the process of transition from traditional to modern and information society, is one of the main catalysts for its development. The launch of democratization and globalization used as the main tool leads to the reform of the entire public administration system. As a result, the formation of a new political system and the return of democratic principles and institutions to its structure begins. At the same time, a characteristic feature of the democratization process of transition countries is the high level of corruption [10].

The dynamic development of information and communication technologies and, as a consequence, the formation of the information society requires an appropriate rapid response from the public sector. The modern world is an electronic world that opens wide opportunities and perspectives, blurs borders and promotes interstate communication, communication of central executive bodies with local self-governments, public organizations, citizens, internal communication, cooperation between the public and private sectors.

Modern Ukraine is a meaningful case of a transitional state. Ukraine's integration into the world information space poses new challenges for the state, one of which is to ensure the provision of electronic services by public authorities. The transition to electronic format makes a number of demands on the state and society. The creation of a digital state requires the formation of new, fundamental digital skills in both public administrators and the subjects of these services. E-government is a requirement for public administration reform on the one hand, and a key tool in the fight against corruption in government (political and administrative corruption) on the other.

It is worth noting that modern challenges require modern solutions and reforms, including updating the system of public services by translating them into electronic format. The availability of effective mechanisms for the provision of electronic services in the country, including administrative, institutional and integration, significantly improves their quality. Online public services simplify the state's dialogue with citizens, thus supporting their active civil position.

Organizational mechanisms are a system of public authorities, state institutions, organizations, their functions and powers, relevant organizational links to exercise public influence on all spheres of society in order to ensure their smooth functioning and development. The main components of the organizational mechanism mostly include objects, subjects of public administration, their goals and objectives, principles of activity, as well as functions, methods, approaches to management and organizational structure, the results of their operation [21]. In unstable periods of transition they become a favorable micro-environment for the spread of corrupt practices.

The quality of e-government services depends on the staffing of the government. The essence of staffing is that it is aimed at the formation, development, rational use of personnel in the public sphere, meritocracy and prevention of nepotism, career promotion of friends and relatives.

Another important factor in the provision of egovernment services is the ongoing professional development of civil servants. Computerization, optimization of work requires the acquisition of new knowledge and skills of employees. The personnel mechanism for providing electronic public services is aimed at developing and implementing new approaches to training and retraining of public authorities at all levels.

Distance learning and professional development of public managers, in particular those responsible for providing e-government services online, is gaining popularity, which saves them a lot of time. Learning becomes more accessible and convenient. Employees have the opportunity to study not only on Ukrainian online platforms, but also on foreign or several platforms at the same time. Upon completion of the course, all those who passed the test receive an electronic certificate, which can be considered as 
advanced training. Since the late 90's of the twentieth century, an important component of such training is the development of civic competencies in civil servants [22].

The Organization for Economic Cooperation and Development has identified four main content components that are fundamental in the provision of e-services by a democratic state: information technology, information management, information society, and modern management skills to be taught to both employees and management of the institutions (Table 1).

Table 1. Updated competencies of civil servants in developed countries

\begin{tabular}{|c|c|}
\hline Sphere & Competences \\
\hline $\begin{array}{l}\text { Implementation of } \\
\text { anti-corruption } \\
\text { principles }\end{array}$ & $\begin{array}{l}\text { Ethical leadership } \\
\text { Civic competencies } \\
\text { Performance management }\end{array}$ \\
\hline $\begin{array}{l}\text { Information } \\
\text { technology }\end{array}$ & $\begin{array}{l}\text { Project and program management } \\
\text { E-government } \\
\text { Evaluation of planning and investment } \\
\text { Change management } \\
\text { Public procurement } \\
\text { Ensuring security in the field of information technology and information security } \\
\text { E-government }\end{array}$ \\
\hline
\end{tabular}

The e-government services should definitely be provided within the legal field, and requires the creation of an appropriate strong regulatory framework. The legal mechanism establishes the connection between law and the state, and also indicates the obligation of the state to act on the basis of law. State influence on public relations in all spheres of their life begins with the issuance of statutes and regulations, which establish the appropriate procedure for taking steps to implement these relations.

Current legislation of Ukraine on the regulation of e-government, including technologies for its implementation and use, has several dozen regulations. In these documents, e-government is seen as a component of informatization, not as a separate area. There are also different levels of regulations that indirectly regulate the outlined issue. It should, however, be noted that the emergence of egovernment was preceded by the informatization of government, and today we are talking about the digitalization of public life and governance.

The financial side of providing e-government services is essential. The state alone is not able to cover the costs of digitalization. The purchase of technical equipment, the creation of electronic resources, training and retraining of employees, etc. require significant funds. At the same time, this could be another corruption challenge. This is a problem that needs to be resolved as soon as possible, in particular by attracting investment and expanding cooperation with the private sector, but on mutually beneficial terms.
In order to properly evaluate projects, the state must accurately calculate the costs of their implementation and the expected end result. Understanding the costs, benefits, risks, future investors can use the criterion of net present value as an estimate of the economic value of current investments. This helps identify strengths and weaknesses of the project. And this can be determined by analyzing the previous costs, the cost of creating an electronic portal, operating costs, benefits for government agencies, benefits for citizens and other consumers of e-government services.

At this stage, a public-private partnership takes effect. The main objectives of public-private partnership, which will contribute to the modernization of public administration in general and in the provision of electronic services, include: increasing efficiency of such services, strengthening citizen participation in public administration, facilitating access to public services and public information; increasing transparency of public authorities and eradicating corruption through open access to public information, improving the quality of service delivery by identifying and achieving key performance indicators, eliminating paid fees for public services, transfer of major risks from limited public sector resources to private performers which can better cope with them, increasing competitiveness of public administration and the economic system as a whole, improving commercial efficiency in the provision of public services and public administration, increasing the level of competencies of public servants for better 
management of public services and performing other administrative activities [23].

Public-private partnership has a number of positive features for Ukraine, as it:

- contributes to the growth of management efficiency;

- contributes to improved quality of hardware and software and its maintenance;

- provides accessibility and openness;

- provides flexibility in responding to requests and in working with partners;

- provides an opportunity to adopt best practices from the private sector and implement them in the private sector.

The benefits of implementing electronic public services are the same for both developed and developing countries. Electronic applications are really advantageous and convenient for citizens, businesses and government agencies. They provide citizens, the private and public sectors with access to public information around the clock and on weekends, which significantly improves their quality, eliminating corruption threats. The use of electronic services allows improving the work of public authorities, as they can provide services to all consumers, regardless of their place of residence. The following advantages of providing electronic public services are distinguished:

a) saving time, effort and money of the service consumer;

b) improving the quality of services provided and meeting consumer needs;

c) raising awareness and improving skills in information and communication technologies, the use of the Internet and the use of computer technology, as well as mobile applications;

d) creating new opportunities for business and the public sector;

e) involving citizens in decision-making and policy-making.

We agree with the following list of benefits of providing e-government services, but we will expand it by a few more important points:

a) preventing and combating corruption through open access to electronic declarations of public officials at all levels;

b) access to public authorities for persons with disabilities who are physically unable to reach government offices on their own and spend hours in long queues;

c) the possibility of distance learning for public managers, which is gaining popularity.
Despite the many obvious advantages, such a modernization of the management system has negative sides. The main disadvantages include:

- occurrence of technical problems due to the use of unlicensed software;

- lack of modern material and technical resources both in public authorities and citizens, which is especially acute in small towns and villages;

- lack of financial resources to implement and support these activities,

- low level of digital literacy both in public managers and in the population, especially the elderly.

In our opinion, the disadvantages of providing electronic public services should also include:

- unequal access of citizens to electronic public services not only due to the lack of a computer or smartphone, but also high-speed Internet, or the Internet in general;

- the likelihood of cybercrime;

- interference with the work of public authorities by third parties, which creates a threat of electronic service users' personal data theft.

From a practical point of view, mechanisms for providing e-government services are effective and able to solve the problem. Despite the advantages of such modernization of public administration and the practical importance of mechanisms for providing egovernment services, the shortcomings and risks are significant. This requires finding ways to minimize and eliminate them.

Let us analyze the case of the effectiveness of the Digital State project in Ukraine (Fig. 1).

Figure 1 reflects the approaches proposed by the Digital State project. A digital product provides, taking into account the presence of user identification, to carry out:

legal services (procedures for automatic registration of business entities, registration of rights to real estate, etc.);

administrative services (obtaining permits for construction work, obtaining declarations of readiness of an object for operation, obtaining licenses for certain industries, types of activities, use, etc.);

financial services (agreements on investment activities, permits for the issuance of certificates of the fund of real estate transactions, the issuance of certificates for the right to carry out professional activities in the stock market, etc.);

services in the field of employment (electronic cabinet of a job seeker, submission of applications for the services of the State Employment Service of Ukraine, etc.). 


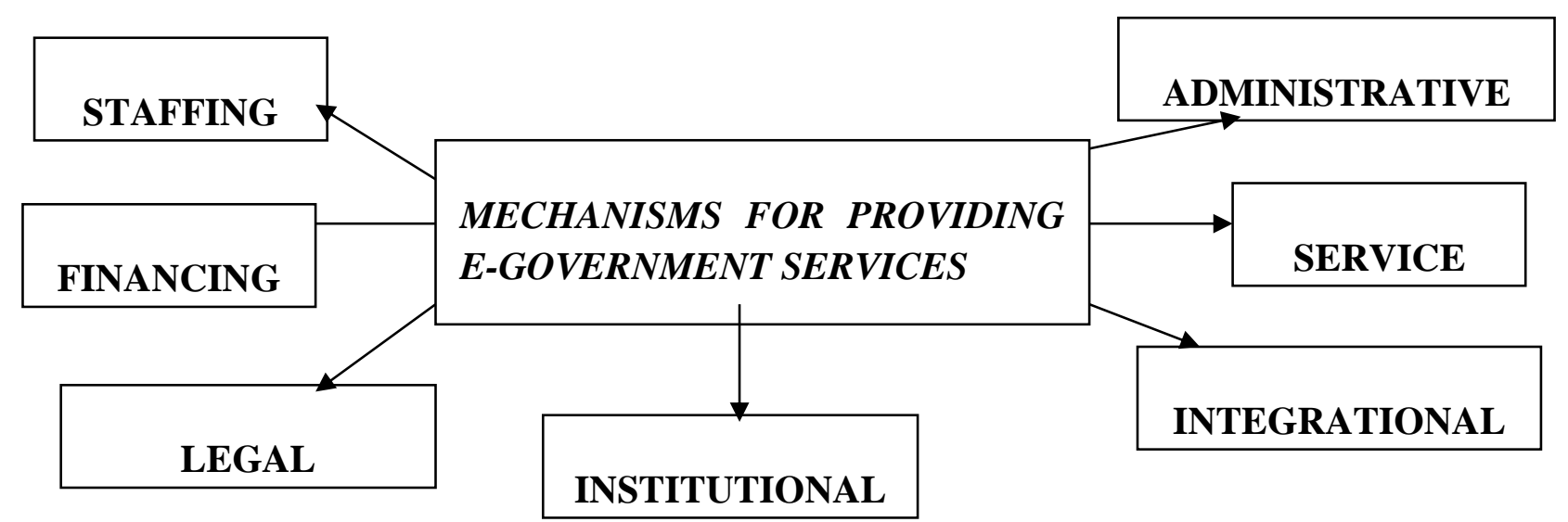

Figure 1. Mechanisms for providing electronic public services

By increasing the capabilities of e-government on the basis of the Digital State project, the institutional ability to provide digital services in education, healthcare, housing and communal services, social and pension provision, culture, security, transport, ecology, etc. is expanding. activities on a single digital platform, the state is trying to strengthen the universality of digital services for society, which will allow conducting transparent business activities, dynamically solving legal, administrative and financial issues of individuals and legal entities. This platform enhances the efficiency of public administration, minimizes corruption risks, shortens the time required for obtaining legal documents, and forms an effective system of integration "statecitizen-society". A significant difference of the proposed approach is the ability to use electronic versions of the ID-card and passport, implemented in a smartphone, which are digital analogs of passports in paper or plastic form. This innovation in the implementation of e-government practices is one of the first in the world, which can significantly reduce manifestations of corruption in interaction with government agencies.

Modern The rapid development of the information society, new innovative technologies and other modern challenges facing our state require providing Ukrainian society with all the necessary tools for its further development. One of those tools is digital transformation (digitization/digitalization), which consists in creating relevant content in digital format. The process of translating information from various fields into digital format is extensive and complex, and requires the cooperation of the state, business, public organizations and citizens.

Digitalization means the introduction of digital technologies in all spheres of life, from the interaction between people and the state to industrial production. Digitalization is one of the main factors in the growth of the world economy in the next 5-10 years. Besides direct productivity gains that digital technologies bring to the companies, there is a number of indirect benefits of digitalization, including time savings, the creation of new demand for new goods and services, new quality and value, etc.

The world is developing the latest digital technologies, including the Internet of Things, robotics and cybersystems, artificial intelligence, large data banks, paperless technology, 3D technology, cloud computing, unmanned and mobile technology, biometric, quantum technology, identification technology, blockchain and more from the IT sphere. Consumers of digital information and communication technologies are both the public and private sectors.

The world practice shows that in order to improve the digital transformation as a way to strengthen and develop digital interaction, it is necessary to adopt a "single principle" which provides that citizens and businesses should only once provide the same information to public authorities. The main premise is that public authorities should reorganize operations in all institutions so that public sector entities can share and reuse data and other information from citizens and businesses, ensuring compliance with national and international standards of data security and privacy.

By universally adopting a "single common principle" and phasing out data exchange between government agencies, combining increased digital literacy training and artificial intelligence technology, public authorities will be able to better understand the needs of citizens and facilitate the provision of services using the latest digital technologies.

Ukraine has only embarked on the path to digitalization and started to take appropriate steps, 
but they should be considered as the first ones. This path is difficult and requires many resources.

In 2019, a new central executive body was established - the Ministry of Digital Transformation of Ukraine. The Regulations on the Ministry of Digital Transformation, approved by the resolution of the Cabinet of Ministers of Ukraine No. 856 dated September 18, 2019, note that the Ministry of Digital Transformation is the main body in the system of central executive bodies that ensures the formation and implementation of state policy in the following areas: digitalization, digital development, digital economy, digital innovation and technology, egovernment and e-democracy, information society development, informatization; introduction of electronic document management; development of digital skills and digital rights of citizens; open data: development of national electronic information resources and interoperability, development of broadband Internet and telecommunications infrastructure, e-commerce and business; electronic and administrative services; electronic trust services and electronic identification; in the development of the IT industry. It also enshrines the main tasks of the Ministry, its functions.

Digitization of the state is based on the relevant principles:

1) creating equal access to necessary services, important information and relevant knowledge provided through information and communication systems;

2) focus on creating benefits in all spheres of social life;

3 ) it is a springboard for economic growth, which provides for full, not partial, coverage of the state by digitalization to achieve the best results;

4) development of the information society, which consists in the creation of own national content and its popularization;

5) integration of Ukraine into the international, including European, market of e-commerce and services;

6) increasing level of public confidence in the government.

The process of transition from a closed bureaucratized state to an open service state provides for a radical transformation of all spheres of public life. Thus, the key elements of the Digital State project include:

- e-government;

- cybersecurity;

- e-democracy;

- e-business;

- e-court;

- e-health;
- e-education;

- electronic transport system;

- smart cities;

- digital skills;

- coverage of the entire country by the Internet for equal access of citizens to information and public services.

The state in the smartphone looks more open to citizens, ready to communicate, open to cooperation with the private sector, transparent, understandable. Through appropriate applications installed on the smartphone, you can remotely receive government services, join management processes, participate in public policy making and more.

Here are some examples of digital service in Ukraine. Recently, the project of electronic portal of public services - iGOV - was created. It includes the most relevant and requested services in various spheres of life, which are provided to both citizens of Ukraine and foreign citizens, public associations, as well as a large list of business services. These services are, however, provided partly in electronic form only in the pilot regions of Ukraine, while they are not yet available in others.

The largest project of the Cabinet of Ministers of Ukraine implemented by the Ministry of Digital Transformation is the Digital State project. As part of it, there is a single state web portal of electronic services - Diia, as well as a mobile application, pages on social networks for ease of use and responsiveness. However, not all services can be received remotely.

In general, the formal confirmation of the start of digital policy-making in Ukraine was the adoption in early 2018 of the Concept of Development of the Digital Economy and Society of Ukraine for 20182020. This document contains the main goals and principles of digital development of the country, as well as an indicative plan for their implementation. But this is not enough when it comes to the need for synchronized development of each individual area of the process of harmonization of Ukrainian digital market in the context of the Eastern Partnership policy, namely:

- rules for the provision of telecommunications services and digital infrastructure;

- trust and security in the digital economy;

- electronic trade (eCommerce, eCustoms and eLogistics);

- digital skills;

- research in the field of information and communication technologies, innovations and startup ecosystems;

- e-health. 
At this stage of the country's digitalization, the main obstacle is the lack of a coherent strategic approach to policy-making to harmonize digital markets with the EU and the Eastern Partnership region. The first step towards the implementation of the Concept of Development of the Digital Economy and Society of Ukraine should be the development of strategic documents, road maps, action plans for each of the above areas of digital development of the country.

In our opinion, further steps are needed, which should be included in the agenda of the responsible authorities.

1. In the field of legislative and regulatory support:

- introduction of broadband Internet access as a universal service, development of technical specifications for it;

- creation of a system for monitoring the quality of broadband Internet access services to protect consumer rights;

- creation of a legislative mechanism that will provide local governments with opportunities to assist telecommunications operators.

2. Analysis of the current state of Internet access.

3. Creating a single database of infrastructure, telecommunications networks, market participants, telecommunications and infrastructure mapping.

4. Start of monitoring the state of digital infrastructure (including analysis of the state of competition between all service providers in the digital markets of Ukraine, analysis and monitoring of compliance of Ukrainian legislation with EU standards in the field of telecommunications).

5. Introduction of motivational tools by the state for both users and providers.

The existing laws in Ukraine "On Electronic Digital Signature" and "On Electronic Documents and Electronic Documents Circulation" need to be updated in accordance with the Association Agreement in the context of the transition to full regulation of trust electronic services. The Law of Ukraine "On Protection of Information in Automated Systems" also needs to be brought in line with the new legislation.

It is also important to continue working on further implementation of the law "On Electronic Trust Services" after its adoption - there are more than 25 regulations and an even larger list of standards next in turn in Ukraine. The issue of verification of the electronic digital signature at the time of deposit of archival electronic documents remains unresolved. Therefore, the transition of government agencies into electronic document management may slow down in the near future.
In our opinion, the following can be the primary recommendations in the process of implementing the Digital State project in Ukraine:

1) adapt regulations for the implementation of the Laws of Ukraine "On Electronic Trust Services" and "On the Basic Principles of Cyber Security of Ukraine";

2) lay the foundations of regulatory and technological regulation for electronic identification and create conditions for the legalization of new technologies;

3) review and agree on the lists and content of electronic trust services; clearly define the need for an electronic digital signature as a component of an electronic document in the implementation of egovernment and e-democracy;

4) support state-owned providers of electronic trust services, regardless of market fluctuations and trends;

5) develop a new plan for the implementation of the Cyber Security Strategy of Ukraine agreed with European partners and all stakeholders.

The Diia application, which became available to Ukrainians in 2020, was planned as a platform containing an electronic public services portal (a "single window" platform) and an information system. The platform currently provides citizens and businesses with comprehensive information on available government electronic services, provides them with the opportunity to receive quality services in electronic format, based on a unique service design.

The Diia platform also contains an electronic user account. The main concept of creating an electronic account is to create a single access point that allows citizens to get such access and the necessary information.

The user's personal electronic account does not store personal data. Instead, it displays current information about the citizen from state registers and provides quick and convenient access to other electronic offices and services without requesting additional authorization. The user's personal electronic account is also an element of the public electronic services platform [24].

At the initial stage, the project covers the most important areas of life and addresses the most pressing issues. The Digital State project is effective in general, touches on many important areas and issues that previously took at least a month to address.

The effectiveness of the Digital State project is not yet high. Remote towns and villages, the elderly and low-income families cannot afford a smartphone, high-quality internet, some citizens simply lack 
knowledge and digital skills. At present, we can judge about the effectiveness of the Digital State project from a theoretical point of view only. This project has a number of advantages and disadvantages, like any other social phenomenon.

\section{Discussions}

Modern foreign scholars consider the introduction and functioning of e-government as an anticorruption practice in the implementation of national models of political modernization to be a promising research topic. This situation is due to the positive international experience in the use of e-government in the field of public administration and democratization of the political system.

Based on the case of Digital State project implementation in Ukraine, a positive correlation of the Government to Citizens approach of egovernment with the implemented models of anticorruption practices and reduction of corruption was proved. Therefore, we can say that the proposed methodological approach of correlating successful anti-corruption practices with the information and communication opportunities of the modern world, including transition countries, is quite methodologically comprehensive. In the course of study we identified the features of implementation and functionality of e-government at the national level in the implementation of anti-corruption policy at the present stage of political modernization of transition countries. It is quite important in this process to determine the value, as well as institutional and organizational resources for the implementation of the e-government approach.

It should, however, be noted that in a number of countries of the so-called "old" democracy, great importance in the process of overcoming corruption is given to the professionalization of civil service personnel, developing ethical leadership in the civil service and increasing the level of civic competence of civil servants $[25,26]$. Civic competencies are a dynamic system of knowledge, attitudes, values, abilities and personal qualities that together enable a person to act effectively in a civil society, to exercise human and civil rights and freedoms, and to promote free, harmonious personal development [27]. Developed civic competencies reflect aspects of autonomy, responsibility, motivation as personal qualities of a civil servant, and his focus on the realization of civic values, making responsible decisions in a situation of choice. Democratic competencies are components of civic competencies, they are person's ability to actively and effectively exercise their civil rights and responsibilities, creatively and responsibly develop a culture of democracy in the context of a developed (consolidated) democracy.

Professional activity requires the spirit of civic consciousness of a civil servant, inseparable from respect for current legislation, positive responsibility, a constant balance, reasonable harmony of state, public, personal values in decisions and actions, the belief in combating particular values in the civil service, objectively instrumentalizing moral and ethical knowledge. Spiritual and moral values are a real resource of true individual freedom, political pluralism, and the rule of law [28, 29]. Thus, the culture of civic consciousness for the professional activities of civil servants is a kind of culture of integrity, which is the basis for the ability to harmonize communication with society, prevent abuse of office [30, 31].

The socio-political nature of the civil service is determined by the focus on achieving the public good (public interest) as a goal of public development and depends on the civic competencies acquired by civil servants [13]. This should be the main safeguard and the main tool to prevent corruption. The inner orientation of the individual to the interests of society, the focus on continuous self-improvement for the public good are expressed in civic consciousness, which reflects the characteristics of public and universal personal essence of a civil servant, along with professional one [32].

Awareness of the indisputable value of the public interest, ensuring the priority of the common good of citizens over personal, private or corporate interests are one of the basic principles of professional activity of civil servants [33, 34]. Public interests are the interests of the social community, without which it is impossible to realize private interests on the one hand, and to ensure the integrity, stability and proper functioning of organizations, states, nations, society and their development, respectively, on the other. In our opinion, public interests are the integrated concept for designating the starting point and determining the functions, goals, responsibilities of fair activities of public administration employees.

A significant increase in the types of egovernment services gives rise to problems associated with the human factor, subjectivity in the mechanisms for making managerial decisions, and the lack of the required number of databases with digitized information. This can lead to the inhibition of communications, both between public authorities and with consumers of public services. Given the rapid development of artificial intelligence (AI) technologies, it would be expedient to integrate this 
technology into the e-government system [35], which relies on the existing platform of the "Digital State".

AI technologies may be appropriate:

in the processes of identification of persons and verification of documents during communications with the e-government system;

when accompanying the actions of the consumer of services as advice on the features of the interface;

as an interactive survey and questionnaire survey of service consumers for subsequent individual consideration of their interests and needs;

in the processes of operational control over the operation of the system, monitoring the actions of the parties to active processes, cases of unlawful interference in the operation of e-government services, identifying inconsistencies, vulnerabilities and cyber attacks;

when modeling, forecasting and analyzing the development of certain areas of activity in the egovernment system.

Having as a database the results of consumer interaction with the interface in the Digital State platform, it is possible to use a machine learning method called deep learning [36]. This method allows predicting the result based on a set of input data, which is quite valuable in the e-government system, which needs to implement the functions of organization, planning, motivation, coordination and control.

Determining the most effective models of anticorruption practices in the global world remains topical in modern scientific discourse. The role of egovernment in political modernization can be clearly defined by conceptual understanding of the possibilities and the need to use modern innovation and communication developments in public administration and, in particular, the introduction of e-government (as one of the mechanisms of democratization and prevention of corruption) [7].

It is necessary to dwell separately on the anticorruption effect of the implementation of the Digital State project in Ukraine. The gradual transition to digital analogs of documentation, remote communications and the provision of public services on the basis of a single platform enhances the transparency of administrative procedures, increases the availability of information on the activities of public authorities, minimizes communication with representatives of public authorities, creates up-todate registers of recipients of social benefits, allows for automated control for various areas of activity, increases openness and accountability of decisionmaking, offers broad feedback.

Therefore, e-government can be defined as an information and communication method to improve the governance and anti-corruption system [37]. The results of this analysis allowed developing sound recommendations and programs for the implementation of the e-government system at the present stage in the process of political modernization of transition countries.

\section{Conclusion}

Ukraine as a case of a transition country on the way to the introduction of the digital state is only taking the first steps [8]. We can talk about the implemented appropriate mechanisms for the provision of electronic public services, including organizational (administrative), institutional, integration, service, as well as legal, personnel and financial. They are quite effective, but need to be consistently strengthened with appropriate resources. Each mechanism is key and needs to be integrated to ensure the best results. There are no opportunities for a comprehensive evaluation of the results of introducing the "digital state" in Ukraine. As a transitional state, Ukraine is still at the initial stage of e-government development.

The main advantages of providing egovernment services are preventing and combating corruption through open access to electronic declarations of public administrators at all levels, access to government agencies for people with special needs who cannot physically get to government offices and stand in line for a long time, the possibility of distance learning for public managers. The main disadvantages are the unequal access of citizens to e-government not only due to the lack of a computer or smartphone, but also highspeed Internet or the Internet in general, the risks of cybercrime and attacks on government servers.

The Digital State project implemented by the Ministry of Digital Transformation is quite powerful and large-scale. It aims at integrating all government agencies into a single online system for convenience and speed of use, leveling corruption risks and threats.

This service will make access of citizens and businesses to public services easier, and the state itself - more open and ready for communication and cooperation. Most services are already available in test mode in the pilot regions of Ukraine. Despite its obvious advantages (provision of public services and communication of citizens with the state online), this project has its drawbacks, including the threat of service users' personal data theft, inadequate quality of Internet coverage, low digital literacy of citizens, especially the elderly. 
In further studies, it is necessary to pay attention to the issues of personal data protection, identification methods and cybersecurity as key areas related to state and personal information, reliability and issues of maintaining the security of the egovernment system.

\section{References:}

[1] Abu-Shanab, E. A., Harb, Y. A., Al-Zoubi, S. Y. Government as an Anti-Corruption Tool: Citizens Perceptions. International Journal of Electronic Governance, Vol. 6, 2013, pp. 232248.

[2] Arvidsson, A. The revolution that wasn't: investigating barriers to platform-based eservice delivery partnerships. In Sprague, R. H. (Ed.), 45th Hawaii International Conference on System Sciences, pp. 2633-2642. Institute of Electrical and Electronics Engineers, 2012.

[3] Lörincz, B., Tinholt, D., Van der Linden, N., Colclough, G., Cave, J., Schindler, R. et al. (2010). Digitizing Public Services in Europe: Putting Ambition into Action. http://ec.europa.eu/information_society/newsro om/cf/document.cfm?action=display \&doc_id= 747

[4] Tinholt, D., Colclough, G., Oudmaijer, S., Carrara, W., Tol, T., Schouten, M. et al. EGovernment Benchmark 2012 - INSIGHT Report. 2013. https://www.slideshare.net/gridnev/europeegovernment-benchmark-2012-final-insightreport

[5] Craith, M. N. Culture and Citizenship in Europe. Questions for Anthropologists. Social Anthropology, Vol. 12, No. 3, 2004, pp. 289300.

[6] Montes, G. S., Paschoal, P. C. Corruption: What Are the Effects on Government Effectiveness? Empirical Evidence Considering Developed and Developing Countries. Applied Economics Letters, Vol. 23, No. 2, 2016, pp. 146-150.

[7] Graycar, A. Corruption: Classification and Analysis. Policy and Society, Vol. 34, No. 2, 2015, pp. 87-96.

[8] Brick, T. Bleeding: Diagnosis without an Analysis. Sociologist's Review of the Scandalous Article in "Dzerkalo Tyzhnya". 2018. https://voxukraine.org/uk/krovotechadiagnoz-bez-analizu-retsenziya-sotsiologa-narezonansnu-stattyu-dzerkala-tizhnya/

[9] Moldogaziev, T. T., Liu, C. Public Sector Corruption and Perceived Government Performance in Transition. Governance, Early
View June 2020. (Online). 2020. https://doi.org/10.1111/gove.12519

[10] Transparency International. Corruption Perceptions Index. 2019. https://www.transparency.org/en/cpi/2019/resul ts

[11] Solinthone, P., Rumyantseva, T. E-government Implementation. MATEC The Web of Conferences, Vol. 79, 2016, Art. 01066.

[12] Karabaza, I., Kozhukhova, T. Overcoming Corruption as the Basis of Effective Public Governance and Sustainable Economic Development of the Country, Baltic Journal of Economic Studies, Vol. 4, No. 1, 2018, pp. 181187.

[13] Sumah, S. Corruption, causes and consequences. In V. Bobek (Ed.), Trade and Global Market, pp. 63-79. InTechOpen Ltd, 2018.

[14] Sharafutdinova, G., Steinbuks, J. Governors Matter. A Comparative Study of State-Business Relations in Russia's regions. Economics of Transition, Vol. 25, No. 3, 2017, pp. 471-493.

[15] Johnson, J. E. Fast-Tracked or Boxed in? Informal Politics, Gender, and Women's Representation in Putin's Russia. Perspectives on Politics, Vol. 14, No. 3, 2016, pp. 643-659.

[16] Orlova, A. V., Boichev, V. Corruption Is Us: Tackling Corruption by Examining the Interplay between Formal Rules and Informal Norms within the Russian Construction Industry. Journal of Developing Societies, Vol. 33, No. 4, 2017, pp. 401-427.

[17] Kazakovtseva, M., Gumarova, F., Tsaregorodtsev, E. Forming of Competitive Advantages of Regional Agrarian and Industrial Complex as Mechanism of Ensuring Economic Safety. Mediterranean Journal of Social Sciences, Vol. 6, No. 3, Suppl. 7, 2015, pp. 213220.

[18] Rose-Ackerman, S. Corruption and Government. International Peacekeeping, Vol. 15, No. 3, 2008, pp. 328-343.

[19] Zhou, H. Strategic Stability in Cyberspace: A Chinese View. China Quarterly of International Strategic Studies, Vol. 5, No. 01, 2019, pp. 8195.

[20] Organisation for Economic Co-operation and Development. Digital transformation of public service delivery. In: Government at a Glance 2017, pp. 202-203. OECD, 2017.

[21] Ukrainian Institute of the Future. Ukraine 2030E - a Country with a Developed Digital Economy, 2018. https://strategy.uifuture.org/kraina-zrozvinutoyu-cifrovoyu-ekonomikoyu.html 
[22] Council of Europe. Declaration and Programme of Action 99(76) of the Committee of Ministers on Education for Democratic Citizenship Based on the Rights and Responsibilities of Citizens. 1999.

https://wcd.coe.int/ViewDoc.jsp?id=447269\&S ite $=\mathrm{CM}$

[23] Bugli Inosenti, E. Sovereign-Private Partnership in the System Electronic Regulation. 2015. http://ppp-ukraine.org/wpcontent/uploads/2015/03/PPPs-in-e-GovGuide_ukr.pdf

[24] European Commission. Digital Public Administration Factsheet 2020 Ukraine, 2020. https://joinup.ec.europa.eu/sites/default/files/inl ine-

files/Digital_Public_Administration_Factsheets _Ukraine_vFINAL_0.pdf

[25] Volpp, L. The culture of Citizenship. Theoretical Inquiries in Law, Vol. 8, No. 2, 2007, pp. 571-602.

[26] Wauters, P., Declercq, K., Van der Peijl, S, Davies, P. Study on the Cloud and Service Oriented Architectures for E-Government. Final Report.

2011.

http://europa.formez.it/sites/all/files/Summary \%20Report.pdf

[27] Semenets-Orlova, I. Education for democratic citizenship and human rights education as a means of forming of the culture of citizenship. In N. Protasova (Ed.), Civic Competences in Vocational Education of Civil Servants and Local Government Officials, pp. 66-87, Osnova, 2016.

[28] Starkey, H. Democratic Citizenship, Languages, Diversity and Human Rights: Guide for the Development of Language Education Policies in Europe. From Linguistic Diversity to Plurilingual Education. Council of Europe, 2002.

[29] Akimov, O., Troschinsky, V., Karpa, M., Ventsel, V., Akimova, L. International experience of public administration in the area of national security. Journal of Legal, Ethical and Regulatory Issues, Vol. 23, No. 3, 2020, pp. $1-7$.

[30] Green, M. Global Citizenship: What Are We Talking About and Why Does It Matter? Trends and Insights for International Education Leaders, Vol. 8, 2012, pp. 1-3.

[31] Semenets-Orlova, I., Kyselova Y. Multidimensional Management Contemporary: Generation of Social Meanings for a New Collective Identities. Public Management, Vol. 4, No. 14, 2018, pp. 264-269.
[32] The Institute for Public-Private Partnerships. Public Private Partnership in E-Government: Knowledge Map. InfoDev, 2009.

[33] Ivchenko, Y. Civic Patriotism as the Basis of National Unity (Philosophical and Legal Aspects), Entrepreneurship, Economy and Law, Vol. 9, 2017, pp. 223-226.

[34] Agostino, G., Dunne, J. P., Pieroni, L. Government spending, Corruption and Economic Growth. World Development, Vol. 84, No. C, 2016, pp. 194-205.

[35] Misuraca, G., van Noordt, C., Boukli, A. The use of AI in public services: results from a preliminary mapping across the EU. In Proceedings of the 13th International Conference on Theory and Practice of Electronic Governance, 2020, pp. 90-99. Association for Computing Machineryю

[36] Alexopoulos, C., Lachana, Z., Androutsopoulou, A., Diamantopoulou, V., Charalabidis, Y., Loutsaris, M. A. How machine learning is changing e-government. In Proceedings of the 12th International Conference on Theory and Practice of Electronic Governance, 2019, pp. 354-363. RMIT University.

[37] Kalyayev, A., Efimov, G., Motornyy, V., Dzianyy, R., Akimova, L. Global Security Governance: Conceptual Approaches and Practical Imperatives. In Soliman, K. S. (Ed.), Proceedings of the 33rd International Business Information Management Association Conference, IBIMA 2019: Education Excellence and Innovation Management through Vision 2020, pp. 4484-4495. International Business Information Management Association, 2019.

\section{Contribution of individual authors to the creation of a scientific article (ghostwriting policy)}

All Authors contributed equally to the creation of the given scientific article

\section{Creative Commons Attribution License 4.0 (Attribution 4.0 International, CC BY 4.0)}

This article is published under the terms of the Creative Commons Attribution License 4.0 https://creativecommons.org/licenses/by/4.0/deed.en_US 